PSYCHOLOGIA ROZWOJOWA, $2019 *$ tom 24 , nr 1, s. 85-96

doi:10.4467/20843879PR.19.005.10596

www.ejournals.eu/Psychologia-Rozwojowa

SARA FILIPIAK (D) orcid.org/0000-0001-7818-7168

Instytut Psychologii, Uniwersytet Marii Curie-Skłodowskiej, Lublin Institute of Psychology, Maria Curie-Skłodowska University, Lublin e-mail: s.filipiak@poczta.umcs.lublin.pl

BEATA ŁUBIANKA (D) orcid.org/0000-0003-3255-7260

Instytut Pedagogiki i Psychologii, Uniwersytet Jana Kochanowskiego, Kielce Institute of Education and Psychology, The Jan Kochanowski University, Kielce e-mail: beakta@wp.pl

\title{
Poczucie kontroli w okresie wczesnej adolescencji wśród uczniów z dwóch etapów edukacji
}

\section{Locus of Control in Early Adolescence among Students at Different Education Stages}

\begin{abstract}
The article presents the results of research on the locus of control in early adolescence among students from two different stages of education: primary school and junior high school, participating currently in the education system transformations. The results are a summary of the first stage of a longitudinal project concerning the development of some personality variables among students. 1015 adolescents were examined with Locus of Control Questionnaire (Krasowicz-Kupis, Kurzyp-Wojnarska, 1990), in the school year 2016/2017. The results indicate an indefinite locus of control in situations of successes, failures and in generalized locus of control. The locus of control is shifted significantly more towards external control in students from junior high school, compared to primary school students and it pertains to successes, failures and generalized locus of control. Boys from primary schools are significantly more internal as regards successes and generalized locus of control compared to boys from junior high schools.
\end{abstract}

Keywords: locus of control, early adolescence, stage of education.

Słowa kluczowe: poczucie kontroli, wczesna adolescencja, etap edukacji.

\section{WPROWADZENIE}

W artykule zaprezentowano wstępne wyniki badań prowadzonych w roku szkolnym 2016/2017, które odnoszą się do poczucia kontroli uczniów szkół podstawowych i gimnazjalnych. Przedstawione wyniki stanowią podsumowanie pierwszego etapu badań podłużnych zaplanowanych na lata 2016-2019. Dotyczą one kształtowania się wybranych zmiennych osobowościowych, w tym poczucia kontroli, wśród młodzieży szkolnej uczestniczącej w zmianach struktury organizacji edukacji. Badania prowadzone są z tą samą grupą młodzieży, jednokrotnie w każdym roku szkolnym, w trakcie kolejnych trzech lat ich nauki. Zastosowanie podłużnej strategii badań pozwoli na poznanie przebiegu zmian rozwojowych w obszarze poczucia kontroli (Brzezińska, 2010).

Kontekstem prowadzonych badań była ówcześnie - w 2016 roku - planowana, a obecnie od 1 września 2017 roku realizowana reforma 
edukacji, wygaszająca naukę w gimnazjach, a reaktywująca ośmioletnią naukę w szkołach podstawowych (Ustawa z dnia 14 grudnia $2016 \mathrm{r}$. Prawo oświatowe). Badani w roku szkolnym 2016/2017 szóstoklasiści byli pierwszym rocznikiem, który nie musiał rekrutować się do szkół gimnazjalnych. Gimnazjaliści byli natomiast ostatnim rocznikiem finalizującym wygaszaną aktualnie edukację gimnazjalną. Ten odmienny kontekst szkolny związany z poczuciem nowości sytuacji mógł być dla badanych uczniów źródłem innej oceny oddziaływania sytuacji społecznej, w jakiej się znaleźli, na ich poczucie wpływu na zdarzenia. Ze względu na założenia procedury badań warto dodać, że niemożliwe byłoby w przyszłości objęcie badaniami uczniów w okresie wczesnej adolescencji będących na dwóch etapach edukacji, gdyż tych etapów, w myśl obowiązującego prawa oświatowego, już nie będzie. Autorki badań założyły, że w tak ważnym zarówno społecznie, jak i rozwojowo momencie życia uczniom towarzyszyć może poczucie nowości oraz niepewności sytuacji, w jakiej się znaleźli. To z kolei może oddziaływać na zmiany w zakresie poczucia kontroli, które jako wymiar osobowości pozwala przewidzieć zachowanie człowieka w różnych sytuacjach (Drwal, 1995). Poczucie kontroli odgrywa ważną rolę w prognozowaniu osiągnięć szkolnych oraz jakości przystosowania się ucznia do wyzwań edukacyjnych (Poziemska, 2015). Jak zauważa Katarzyna Barani (2006), można je uznać za czynnik chroniący lub czynnik ryzyka tego, jak adaptuje się nastolatek do nowych wymagań po zmianie etapu edukacji. Doświadczanie przez uczniów społeczno-edukacyjnych zmian nabiera dla nich szczególnego znaczenia. Może ono przyczyniać się do przeobrażeń spostrzegania ich wpływu na zdarzenia związane z osiąganiem celów edukacyjnych. Jakość adaptacji szkolnej stanowi bazę dla pomyślnego realizowania obowiązku szkolnego przez uczniów w trakcie kolejnych lat oraz osiągania dobrostanu psychologicznego związanego z kształtowaniem się pozytywnego obrazu siebie jako ucznia, a także kolegi (Farnicka, Liberska, 2015; Farnicka, Liberska, Nurmi, 2016).

Prowadzone badania wpisują się w nurt analiz związanych zarówno z psychologicznym opi- sem funkcjonowania młodzieży na różnych etapach edukacji (Turska, 2003), jak i poznaniem oraz zrozumieniem oddziaływania społecznych czynników - w tym przypadku edukacyjnych na przebieg zmian rozwojowych u młodzieży bezpośrednio ich doświadczających (Dudzikowa, Wawrzyniak-Beszterda, 2010; Kulas, 1996; 1998; Woynarowska, Małkowska-Szkutnik, Woynarowska-Soldan, Mazur, 2015).

\section{Miejsce poczucia kontroli w badaniach psychologicznych}

Wywodzące się z teorii społecznego uczenia Juliana B. Rottera pojęcie poczucia lokalizacji kontroli (locus of control - LOC) jest ważną zmienną osobowościową pomocną przy wyjaśnianiu i przewidywaniu zachowania człowieka (Rotter, 1966). Analizy odnoszące się do poczucia kontroli sięgają początków drugiej połowy XX wieku i wciąż podejmowane są w badaniach psychologicznych (por. Barani, 2006; Chubb, Fertman, Ross, 1997; Domachowski 1984; Domańska-Najder, 1984; Drwal, 1995; Gliszczyńska, 1990; Landis, Altman, Cavin, 2007; Marks, 1998; Ng-Knight, Schoon, 2017; Smith, 2003).

Poczucie kontroli odnosi się do tego, jak człowiek spostrzega przyczyny różnych zdarzeń. Zmienną poczucia kontroli można umiejscowić na kontinuum od zewnątrz- do wewnątrzsterowności. Osoby, u których poczucie kontroli jest przesunięte ku wewnętrznemu, dostrzegają związki pomiędzy własnymi działaniami a skutkami zdarzeń, osoby z zewnętrznym poczuciem kontroli zaś są skłonne upatrywać przyczyn zdarzeń ze swojego życia bardziej w czynnikach pozaosobowych (Marks, 1998; Rotter, 1966). Poczucie kontroli ma istotne znaczenie dla funkcjonowania człowieka w codziennych sytuacjach oraz dla jego zdrowia fizycznego i psychicznego (Moshki, Ashtarian, 2010; Woynarowska i in. 2015) oraz, jak pisze Henryk Kulas (1996), powiązane jest ściśle z prawidłowym rozwojem osobowości, szczególnie u młodzieży.

Poczucie lokalizacji kontroli nie jest stałą właściwością osobowości. H. Kulas (1998) podaje, że kształtuje się ono w okresie dzieciństwa 
i adolescencji. Wśród czynników wpływających na jego rozwój można wymienić między innymi oddziaływania wychowawcze sprzyjające poczuciu odpowiedzialności za podejmowane działania oraz postępujący rozwój poznawczy, w tym nabywanie sprawności w logicznym wyjaśnianiu przyczyn zdarzeń i ich konsekwencji (Piaget, 1974). Współczesne badania wskazują również, że poczucie kontroli może być także rezultatem mózgowych procesów samoregulacyjnych, które nadają zachowaniu elastyczność w doborze sposobów działania oraz wywierania wpływu na otoczenie (Declerck, Boone, De Brabander, 2006).

Irv Bialer (1961) oraz Herbert Lefcourt (1976) analizowali zmiany rozwojowe poczucia kontroli wraz z wiekiem i wykazali, że $z$ upływem lat wzrasta wewnętrzne poczucie kontroli zdarzeń, czemu sprzyja wzrost niezależności dziecka i jego możliwości wpływania na środowisko fizyczne oraz społeczne. Zależność między wiekiem a poczuciem kontroli nie ma jednak charakteru liniowego, czego przykładem są wyniki badań H. Kulasa (1998). Autor na podstawie badań podłużnych wykazał, że pomiędzy późnym dzieciństwem a wczesną adolescencją występują zmiany rozwojowe polegające na przesunięciu poczucia kontroli w kierunku zewnętrznego. Poczucie kontroli wewnętrznej zwiększało się z kolei u tych samych uczniów między czwartą a siódmą klasą. Autor tłumaczył wzrost poczucia kontroli zewnętrznej w pierwszym etapie badań (między trzecią a czwartą klasą szkoły podstawowej) zmianą środowiska i wymogów szkolnych. Ta nowa sytuacja prawdopodobnie mogła powodować niepewność i przynajmniej chwilowe poczucie braku wpływu na otaczającą rzeczywistość. Dodatkowe analizy wykazały, że, w porównaniu z chłopcami, dziewczynki w okresie wczesnej adolescencji charakteryzowały się istotną statystycznie wyższą skłonnością do przypisywania przyczyn różnych zdarzeń czynnikom zewnętrznym. Inne podłużne badania H. Kulasa (1996) prowadzone na 84-osobowej grupie młodzieży wykazały, że około 15. roku życia zwiększa się zewnętrzne poczucie kontroli, co ma związek ze zmianą etapu edukacji.
Przedstawione rezultaty badań pozwalają stwierdzić, że dla rozwoju poczucia kontroli istotnego znaczenia nabierają sytuacyjne czynniki zewnętrzne, takie jak zmiana szkoły lub przejście do kolejnego etapu edukacji. Barbara Szmigielska (1981), badając poczucie kontroli u młodzieży w wieku szkolnym, zauważyła, że najwyższe wskaźniki zewnętrznego poczucia kontroli były charakterystyczne dla uczniów 14- i 15-letnich, czyli tych, którzy kończyli szkołę podstawową i przechodzili na kolejny etap kształcenia. Autorka podkreśla jednocześnie, że aby można było dokonać rekonstrukcji zmian rozwojowych poczucia kontroli, należałoby uwzględnić szersze okresy rozwojowe.

\section{Rola poczucia kontroli w rozwoju młodzieży w okresie wczesnej adolescencji}

Wczesna adolescencja to okres w życiu człowieka od 12. do 15. roku życia (Obuchowska, 2009). Jest to czas związany przede wszystkim z aktywnością szkolną. Barbara Woynarowska, Agnieszka Małkowska-Szkutnik, Magdalena Woynarowska-Soldan i Joanna Mazur (2015) stwierdzają, że środowisko szkoły u nastolatków można porównać do miejsca pracy u osób dorosłych. Dla dorastających młodych osób szkoła, równolegle do domu rodzinnego, jest miejscem nie tylko podstawowej aktywności życiowej, ale i obszarem kształtującym ich osobowość (Bardziejewska, 2005; Dekovic, Meeus, 1997; Obuchowski 1985). Przebieg zmian rozwojowych w okresie wczesnej adolescencji dotyczy różnych i wzajemnie powiązanych z sobą sfer funkcjonowania oraz ma zróżnicowany przebieg w zależności od czynników dziedzicznych i społeczno-kulturowych (Kim, 2011; Kulas, 1996).

$\mathrm{W}$ okres wczesnej adolescencji integralnie wpisany jest dynamiczny rozwój i kształtowanie się osobowości (Allik, Laidra, Realo, Pullman, 2004; Kulas, 1996; McCrea, Martin, Costa, 2005). Nancy H. Chubb, Carl I. Fertman i Jennifer L. Ross (1997) zauważają, że w tym czasie poczucie kontroli ulega intensywnym przemianom, stanowiąc odzwierciedlenie wyzwań i trudności, przed jakimi zostają postawieni i z jakimi muszą radzić sobie dorastający. 
Autorzy podają także, że posiadane poczucie kontroli pozwala przewidzieć, jak dorastający mogą radzić sobie z wyzwaniami i oczekiwaniami, przed którymi będą postawieni w przyszłości. Prowadzone badania psychologiczne wskazują na związek poczucia kontroli u nastolatków z takimi zmiennymi, jak: zachowania ryzykowne zagrażające zdrowiu (Kim, 2011), przystosowanie rodzinne (Jaworowska, 1982), radzenie sobie ze stresem (Barani, 2006; Butler-Sweeney, 2007), tendencja do zwlekania (Deniz, Traş, Aydoğan, 2009) czy prężność osobowa (Cazan, Dumitrescu, 2016). Wskazuje się także, że poczucie kontroli pozwala przewidzieć poziom osiągnięć szkolnych (Poziemska, 2015; Turska, 2003). Monika Dominiak (2006) wykazała, że średnia ocen szkolnych u dziewcząt i chłopców o wewnętrznym poczuciu kontroli była wyższa niż u młodzieży charakteryzującej się zewnętrznym poczuciem kontroli. W przypadku uczniów zmieniających szkołę lub etap edukacji poczucie kontroli może być czynnikiem determinującym sposób interpretowania nowej sytuacji szkolnej oraz czynnikiem jakości procesu adaptacji do nowego środowiska i nowych wymagań (Barani, 2006). Poczucie zadowolenia wynikające $\mathrm{z}$ uczestnictwa w doświadczaniu różnych sytuacji szkolnych sprzyja pozytywnym osiągnięciom szkolnym i pomyślnemu przebiegowi dalszego kształcenia (Woynarowska i in., 2015). K. Barani (2006), na podstawie badań nad poczuciem kontroli i stylem radzenia sobie w nowej sytuacji szkolnej, stwierdziła, że uczniowie pierwszej klasy gimnazjum przejawiają większą skłonność do szukania przyczyn swoich porażek na zewnątrz, w sytuacjach sukcesów zaś chętniej szukają ich przyczyn w swoich własnych zasobach i działaniach. Wyniki wykazały także, że wewnętrzne poczucie kontroli sukcesów, niepowodzeń oraz uogólnione poczucie kontroli ma związek z aktywnym stylem przystosowywania się uczniów. Inne analizy prowadzone przez Jennifer Butler-Sweeney (2007) wskazują na związki między wewnętrznym poczuciem kontroli a stylem radzenia sobie ze stresem zorientowanym na rozwiązanie problemu oraz wyższym poczuciem własnej wartości u badanych dziewcząt w wieku 13-16 lat. Natomiast Ana M. Cazan i Stefania A.
Dumitrescu (2016) stwierdzają, że wewnętrzne poczucie kontroli powiązane jest z prężnością psychiczną adolescentów. Co ciekawe, Angelika Anderson, John Hattie i Richard J. Hamilton (2005) sformułowali wniosek, że skrajne natężenie wewnętrznego poczucia kontroli i poczucia własnej skuteczności nie sprzyja dobremu przystosowaniu ani osiągnięciom szkolnym. Autorzy ci postulują, że optymalne jest umiarkowane nasilenie obu zmiennych. Warto także wspomnieć o badaniach Wendy Kliewer i Irwin N. Sandler (1992) prowadzonych wśród dzieci i młodzieży między 8. a 16. rokiem życia, dotyczących związków traumatycznych zdarzeń życiowych z poczuciem kontroli oraz nieprzystosowaniem. Wyniki ujawniły, że poczucie kontroli było moderatorem związków między trudnymi wydarzeniami a nieprzystosowaniem, choć otrzymane rezultaty nie miały związku z płcią oraz wiekiem badanych.

Biorąc pod uwagę nieliczne współczesne badania nad kształtowaniem się poczucia kontroli u młodzieży, postanowiono dokonać takiej analizy ze szczególnym uwzględnieniem sygnalizowanych w literaturze przedmiotu ważnych dla zmian rozwojowych sytuacyjnych czynników zewnętrznych.

\section{PROBLEM BADAWCZY}

Głównym celem badań było ustalenie, jak uczniowie w okresie wczesnej adolescencji, będący na dwóch etapach edukacji, różnią się między sobą w zakresie zmiennej osobowościowej poczucia kontroli. Sprawdzono także, jak płeć osób badanych różnicuje wyniki w zakresie poczucia kontroli. Na podstawie zaprezentowanego przeglądu literatury psychologicznej sformułowano następujące pytania i hipotezy badawcze:

\section{Pytania badawcze}

1. Jak na różnym etapie edukacji uczniowie różnią się między sobą w zakresie zgeneralizowanego poczucia kontroli?

2. Jak na różnym etapie edukacji uczniowie różnią się między sobą w zakresie poczucia kontroli w sytuacjach sukcesów i porażek? 
3. Jak dziewczęta i chłopcy różnią się między sobą w zakresie zgeneralizowanego poczucia kontroli oraz poczucia kontroli w sytuacjach sukcesów i porażek?

\section{Hipotezy}

- H1. Uczniowie ze szkół gimnazjalnych w porównaniu z uczniami ze szkół podstawowych częściej charakteryzują się zewnętrznym zgeneralizowanym poczuciem kontroli.

- H2. Uczniowie gimnazjów w porównaniu z uczniami ze szkół podstawowych charakteryzują się przesuniętym ku wewnętrznemu poczuciu kontroli w sytuacjach sukcesów, ku zewnętrznemu zaś - w sytuacjach porażek.

- H3. Dziewczęta częściej niż chłopcy charakteryzują się zewnętrznym poczuciem kontroli w zakresie zgeneralizowanego poczucia kontroli oraz w sytuacjach sukcesów i porażek.

Dotychczasowe badania nad poczuciem kontroli wykazały, że u uczniów doświadczających zmiany w organizacji edukacji wzrastało zewnętrzne poczucie kontroli (Szmigielska, 1981; Kulas, 1998). Z kolei Barani (2006) zaobserwowała, że gimnazjaliści częściej szukali przyczyn swoich porażek w czynnikach zewnętrznych, w przypadku odnoszonych sukcesów zaś w czynnikach wewnętrznych. Dodatkowo Kulas (1998) wskazał, że w okresie wczesnej adolescencji dziewczynki w porównaniu z chłopcami częściej przypisywały przyczyny różnych zdarzeń w swoim życiu czynnikom zewnętrznym.

\section{METODA}

\section{Narzędzia badawcze}

Badanie przeprowadzono przy zastosowaniu dostępnego na czas rozpoczęcia badań - rok szkolny 2016/2017 - Kwestionariusza do Badania Poczucia Kontroli (KBPK) Grażyny Krasowicz oraz Anny Kurzyp-Wojnarskiej (Krasowicz, Kurzyp-Wojnarska, 1990). Zrewidowana wersja narzędzia KBPK-R ukazała się w 2017 roku (Krasowicz-Kupis, Wojnarska, 2017). Test służy do pomiaru zmiennej osobowościowej zwanej poczuciem kontroli następstw zachowania, opisanej w teorii społecznego uczenia się J. Rottera. W skład testu KBPK wchodzi 46 pytań, z czego 36 ma wartość diagnostyczną dla poczucia kontroli. Połowa pytań diagnostycznych dotyczy sytuacji odnoszonych sukcesów, druga połowa sytuacji niepowodzeń. Suma pytań diagnostycznych stanowi wynik ogólny mówiący o zgeneralizowanym poczuciu kontroli. Test charakteryzuje się zadowalającą rzetelnością i trafnością. Wartości alfa Cronbacha dla poszczególnych skal wynoszą odpowiednio: $\mathrm{r}=$ .40 (skala sukcesu), $\mathrm{r}=.54$ (skala niepowodzeń), $\mathrm{r}=.62$ (wynik ogólny). Współczynniki korelacji między KBPK $\mathrm{z}$ innymi miarami poczucia kontroli były istotne statystycznie i zawierały się w przedziale korelacji od niskich do umiarkowanych, co przemawia za zadowalającą trafnością diagnostyczną narzędzia. Test posiada normy dla młodzieży w wieku 13-17 lat.

\section{Osoby badane i procedura}

W badaniu łącznie wzięło udział 910 osób - odpowiednio 455 uczniów z klas szóstych szkół podstawowych i 455 uczniów z klas pierwszych szkół gimnazjalnych. Grupę uczniów klas szóstych szkół podstawowych stanowiły osoby w wieku od 11 do 13 lat $(\mathrm{M}=12,4$; SD $=.58 ; \mathrm{w}$ tym $51 \%$ dziewcząt). Grupę uczniów pierwszych klas gimnazjalnych reprezentowały natomiast osoby w wieku od 12 do 14 lat $(\mathrm{M}=13,4 ; \mathrm{SD}=.53$; w tym $51 \%$ to dziewczęta). Badania zostały przeprowadzone na terenie miasta Lublina w sześciu szkołach podstawowych i czterech szkołach gimnazjalnych. Do badań zostały losowo wybrane zarówno szkoły publiczne, jak i niepubliczne. Autorki artykułu prowadziły badania od grudnia 2016 do czerwca 2017 roku, z zachowaniem należnych etycznych zasad, ze szczególnym uwzględnieniem poufności, anonimowości i dobrowolności udziału osób badanych (Brzeziński, 2008). Badania były prowadzone za zgodą rodziców i przyzwoleniem dyrektora szkoły oraz w konsultacji z psychologiem lub pedagogiem szkolnym. Odbywały się grupowo, zostały zrealizowane w trakcie jednego spotkania z każdą klasą. 


\section{WYNIKI}

Interpretacja ilościowa uzyskanych danych została przeprowadzona na podstawie otrzymanych wyników surowych. Analizy otrzymanych wyników zostały zaprezentowane w kolejności postawionych pytań badawczych. Przedstawiono wyniki w zakresie zgeneralizowanego poczucia kontroli oraz w sytuacjach sukcesów i niepowodzeń uzyskane przez uczniów kształcących się na dwóch etapach edukacji. Następnie sprawdzono, jak dziewczęta i chłopcy różnią się między sobą w zakresie analizowanych zmiennych.

W celu udzielenia odpowiedzi na pytanie, czy istnieją istotne statystycznie różnice pomiędzy uzyskanymi wynikami w poczuciu kontroli uzyskanymi wśród uczniów będących na różnych etapach edukacji, zastosowano test istotności różnic $t$ Studenta dla prób niezależnych. Przed zastosowaniem tego testu sprawdzono w zakresie obliczeń dla każdego pytania badawczego test $F$ jednorodność wariancji Levene'a. Test $F$ okazał się nieistotny statystycznie i uzyskał następujące wartości dla poszczególnych zmiennych w pytaniach badawczych - odpowiednio: pytanie 1 . wynik ogólny $\mathrm{F}=$ $2.433 ; \mathrm{p}=.120 ; 2$. sytuacje sukcesów $\mathrm{F}=4.792$; $\mathrm{p}=.075$; sytuacje porażek $\mathrm{F}=2.351 ; \mathrm{p}=.126$; 3 . wynik ogólny $\mathrm{F}=2.456 ; \mathrm{p}=.117$; sytuacje sukcesów $\mathrm{F}=1.170 ; \mathrm{p}=.280 ;$ sytuacje porażek $\mathrm{F}=3.424 ; \mathrm{p}=.065$.

Autorzy (zob. Barani, 2006; Kulas, 1998) zwracali uwagę na to, że poczucie kontroli u uczniów, którzy przeszli na kolejny etap edukacji, przesuwało się w kierunku zewnętrznego. Postanowiono sprawdzić, jak we współczesnym kontekście zmian edukacyjnych kształtuje się poczucie kontroli w grupie uczniów będących w tym samym okresie rozwojowym, a podążających dwiema różnymi ścieżkami edukacji, z których jedna - gimnazjalna - jest wygaszana. Tym samym, chcąc zaobserwować przebieg tych zmian w perspektywie trzech lat, w punkcie wyjścia porównano wyniki uzyskane w obu grupach w pierwszym etapie badań. Tabela 1 przedstawia wartości średnie i wartości testu $t$ Studenta dla wyniku ogólnego poczucia kontroli otrzymanego przez uczniów z klas szóstych szkół podstawowych oraz klas pierwszych szkół gimnazjalnych.

Tabela 1. Wartości średnie oraz wartości testu $t$ Studenta uzyskane dla wyniku ogólnego poczucia kontroli przez uczniów będących na różnych etapach edukacji: klas szóstych szkół podstawowych i klas pierwszych szkół gimnazjalnych

\begin{tabular}{|l|l|c|c|c|c|}
\hline \multicolumn{2}{|c|}{ Etap edukacji } & M & SD & t & p \\
\hline \multirow{2}{*}{$\begin{array}{l}\text { Zgeneralizowane } \\
\text { poczucie kontroli }\end{array}$} & szkoła podstawowa & 23.00 & 5.54 & \multirow{2}{*}{2.67} & \multirow{2}{*}{$.020^{*}$} \\
\cline { 2 - 4 } & gimnazjum & 22.48 & 6.24 & & \\
\hline
\end{tabular}

$* p<.05$

Badani uczniowie istotnie statystycznie $(\mathrm{p}<.05)$ różnią się pod względem zgeneralizowanego poczucia kontroli w zależności od etapu kształcenia. Otrzymane wyniki $(\mathrm{M}=23.00$; $\mathrm{M}=22.48)$ mieszczą się w obszarze wyników nieustalonych, co oznacza, że poczucie kontroli jest jeszcze nieukształtowane. Warto jednak zauważyć, że otrzymana w teście $t$ Studenta różnica między wynikami dwóch grup wskazuje na to, że u uczniów gimnazjum poczucie kontroli, mimo że jeszcze nieukształtowane, to jest istotnie statystyczne przesunięte $\mathrm{w}$ kierunku kontroli zewnętrznej, w porównaniu z uczniami szkół podstawowych. Tym samym uczniowie klas szóstych częściej niż ich starsi rówieśnicy z klas gimnazjalnych mają poczucie wewnętrznej kontroli następstw zdarzeń oraz chętniej przypisują sobie odpowiedzialność za różne sytuacje w ich życiu.

Dla określenia przebiegu zmian rozwojowych poczucia kontroli ważna jest także analiza tego, jak uczniowie z różnych etapów edukacji odnoszą się do sytuacji związanych z sukcesami oraz doznawanymi porażkami, które spotykają ich teraz lub zdarzyć się mogą w przyszłości. Myślenie o przyczynach swoich sukcesów i niepowodzeń ma wpływ na wybór działań i aktywność człowieka w sytuacjach 
społecznych oraz na gotowość do uczestniczenia w nich. Barani (2006) stwierdza, że uczniowie w pierwszych klasach gimnazjalnych charakteryzują się tendencją do poszukiwania przyczyn doznawanych niepowodzeń w czynnikach zewnętrznych, tkwiących poza nimi, przyczyn sukcesów zaś upatrują w swoich własnych działaniach i zasobach. W odniesieniu do zaprezentowanych wyników badań porównano wyniki uzyskane w skali sukcesu oraz porażek przez uczniów ze szkół podstawowych oraz z gimnazjów. Tabela 2 przedstawia podstawowe charakterystyki opisowe oraz wartości testu istotności różnic dla poczucia lokalizacji kontroli w sytuacjach sukcesów i niepowodzeń wśród uczniów klas szóstych szkół podstawowych oraz pierwszych klas gimnazjalnych.

Tabela 2. Wartości średnie i testu $t$ Studenta uzyskane dla poczucia kontroli w sytuacjach sukcesów oraz niepowodzeń przez uczniów będących na różnych etapach edukacji

\begin{tabular}{|l|l|c|c|c|c|}
\hline Poczucie kontroli & \multicolumn{1}{|c|}{ Etap edukacji } & M & SD & t & p \\
\hline \multirow{2}{*}{ Sytuacje sukcesów } & szkoła podstawowa & 11.92 & 2.85 & \multirow{2}{*}{2.24} & \multirow{2}{*}{$.03^{*}$} \\
\cline { 2 - 4 } & gimnazjum & 11.46 & 3.28 & & \multirow{2}{*}{2.36} \\
\hline \multirow{2}{*}{ Sytuacje porażek } & szkoła podstawowa & 11.62 & 3.53 & \multirow{2}{*}{$.03^{*}$} \\
\cline { 2 - 4 } & gimnazjum & 11.05 & 3.75 & & \\
\hline
\end{tabular}

${ }^{*} p<.05$

Uzyskane wśród uczniów zarówno szkół podstawowych, jak i gimnazjum wyniki poczucia kontroli w sytuacjach sukcesów $(\mathrm{M}=11.92$; $\mathrm{M}=11.46)$ i porażek $(\mathrm{M}=11.62 ; \mathrm{M}=11.05)$ mieszczą się w obszarze wyników nieustalonych. Oznacza to, że wyjaśnianie swoich osiągnięć i niepowodzeń w różnych sytuacjach życiowych stosowane przez młodzież jest jeszcze na etapie kształtowania się. Dodatkowo należy zauważyć, że otrzymane różnice pomiędzy wynikami uczniów na dwóch etapach edukacji wskazują na istotnie statystycznie częstsze wśród gimnazjalistów przesunięcie poczucia kontroli w kierunku zewnętrznego, zarówno w obszarze kon- troli sytuacji sukcesów $(p<.05)$, jak i porażek $(\mathrm{p}<.05) \mathrm{w}$ porównaniu $\mathrm{z}$ uczniami szkół podstawowych (tabela 3 ).

Wyniki badań nad różnicami w poczuciu kontroli pomiędzy dziewczętami a chłopcami są niejednoznaczne. Niektórzy badacze nie wykazują różnic pomiędzy płciami w zakresie poczucia kontroli u nastolatków (Cazan, Dumitrescu, 2016; Anderson, Hattie, Hamilton, 2005). Polskie badania Kulasa (1996) wskazują jednak na występowanie tych różnic w poczuciu kontroli u młodzieży szkolnej. Autor na podstawie trwających trzy lata badań podłużnych stwierdził, że u dziewcząt występowała

Tabela 3. Wartości średnie i test $t$ Studenta dla poczucia kontroli w sytuacjach sukcesów i niepowodzeń u dziewcząt i chłopców będących na różnych etapach edukacji

\begin{tabular}{|c|c|c|c|c|c|c|c|}
\hline \multirow{3}{*}{ Poczucie kontroli } & \multirow{3}{*}{ Płeć } & \multicolumn{4}{|c|}{ Etap edukacji } & \multirow{3}{*}{$\mathbf{t}$} & \multirow{3}{*}{$\mathbf{p}$} \\
\hline & & \multicolumn{2}{|c|}{ szkoła podstawowa } & \multicolumn{2}{|c|}{ gimnazjum } & & \\
\hline & & M & SD & $\mathbf{M}$ & SD & & \\
\hline \multirow{2}{*}{$\begin{array}{l}\text { Zgeneralizowane } \\
\text { poczucie kontroli }\end{array}$} & dziewczęta & 22.78 & 5.80 & 23.28 & 5.48 & 1.864 & n.i. \\
\hline & chłopcy & 23.24 & 6.10 & 23.80 & 5.63 & 1.916 & $.01^{* *}$ \\
\hline \multirow{2}{*}{$\begin{array}{l}\text { Sytuacje } \\
\text { sukcesów }\end{array}$} & dziewczęta & 11.62 & 3.02 & 11.83 & 2.85 & 1.459 & n.i. \\
\hline & chłopcy & 11.76 & 3.14 & 12.02 & 2.85 & 1.709 & $.000 * * *$ \\
\hline \multirow{2}{*}{$\begin{array}{l}\text { Sytuacje } \\
\text { niepowodzeń }\end{array}$} & dziewczęta & 11.19 & 3.51 & 11.47 & 3.43 & 1.694 & n.i. \\
\hline & chłopcy & 11.49 & 3.78 & 11.79 & 3.63 & 1.652 & n.i. \\
\hline
\end{tabular}

$* * p<.01 ; * * *<.001$ 
stała tendencja do przesuwania się poczucia kontroli w kierunku zewnętrznego, u chłopców zaś, u których poczucie kontroli było przesunięte ku wewnętrznemu w pierwszym i drugim etapie badania, w trzecim przesunęło się w kierunku kontroli zewnętrznej. Tym samym kierując się potrzebą poznania zaznaczonej w literaturze przedmiotu rozbieżności co do rozwojowych zmian poczucia kontroli u dziewcząt i chłopców, przeprowadzono w niniejszych badaniach analizy z uwzględnieniem płci.

Wyniki uzyskane przez uczniów i uczennice, zarówno ze szkół podstawowych jak i z gimnazjum, w zakresie zgeneralizowanego poczucia kontroli, poczucia kontroli w sytuacjach sukcesów i porażek mieszczą się w granicach wyników nieustalonych. Wskazuje to na nieukształtowane jeszcze poczucie kontroli wśród dziewcząt i chłopców na różnych etapach edukacji. Otrzymane w teście $t$ Studenta istotne różnice pomiędzy wynikami w zakresie poczucia kontroli z uwzględnieniem płci badanych osób dotyczą tylko chłopców. Odpowiedzi udzielane przez gimnazjalistów istotnie statystycznie częściej niż przez ich rówieśników ze szkół podstawowych wskazują na przesunięcie poczucia kontroli w kierunku wewnętrznego, zarówno w obszarze zgeneralizowanego poczucia kontroli $(\mathrm{p}<.05)$, jak i w sytuacji poczucia sukcesu $(\mathrm{p}<.001)$. Tym samym chłopcy z gimnazjum częściej przypisują sobie, własnym działaniom i wysiłkowi wyjaśnianie przyczyn sytuacji, które ich spotykają.

Dodatkowo przeprowadzono także analizy dotyczące różnic w poczuciu kontroli pomiędzy dziewczętami a chłopcami, osobno dla każdego etapu edukacji. Wyniki te okazały się nieistotne statystycznie, co oznacza, że zarówno w szkołach podstawowych, jak i gimnazjach dziewczęta nie różnią się od chłopców w zakresie wyjaśniania przyczyn sukcesów, niepowodzeń oraz zgeneralizowanego poczucia kontroli.

\section{DYSKUSJA WYNIKÓW}

Poczucie kontroli odpowiada za subiektywną ocenę sytuacji zewnętrznej w kategoriach zagrożenia lub szansy rozwojowej. Tym samym jest istotnym zasobem radzenia sobie w sytu- acjach nowych i nieprzewidywalnych. Osoby, które mają poczucie wpływu na rzeczywistość, szybciej adaptują się do nowej sytuacji i ponoszą mniej kosztów psychologicznych związanych z koniecznością przystosowania się do nowych wymagań. Poczucie kontroli może przekładać się na pomyślne realizowanie obowiązku szkolnego, wyrażonego w poziomie osiągnięć edukacyjnych oraz gotowości uczniów do uczestnictwa w przedsięwzięciach rozwijających ich umiejętności społeczne i osobiste.

Średnie wyniki w zakresie poczucia kontroli uzyskane w niniejszych badaniach przez uczniów zarówno ze szkół podstawowych, jak i gimnazjalnych wskazują, że jest ono nieustalone, czyli pozostaje w trakcie kształtowania się. Analizy statystyczne wykazały jednak, że uczniowie z pierwszych klas gimnazjum różnią się w zakresie poczucia kontroli w porównaniu z uczniami z szóstych klas szkół podstawowych. Poczucie kontroli sukcesów, niepowodzeń oraz zgeneralizowane poczucie kontroli u uczniów $\mathrm{z}$ gimnazjum przesunięte jest w kierunku zewnętrznego. Oznacza to, że hipoteza pierwsza mówiąca o tym, że gimnazjaliści w porównaniu z uczniami ze szkół podstawowych częściej charakteryzują się zewnętrznym zgeneralizowanym poczuciem kontroli, się potwierdziła. Można zatem wnioskować, że uogólnione myślenie gimnazjalistów o swoich możliwościach sprawowania kontroli nad przebiegiem zdarzeń wskazuje na to, że wpływ ten jest ograniczony. Różnica wieku między uczniami ze szkół podstawowych $(\mathrm{M}=12.40)$ i gimnazjalnych $(\mathrm{M}=13.40)$ wynosi rok. Wskazuje się, że nie tyle sam w sobie wiek chronologiczny stanowi czynnik rozwoju, ile kumulacja nowych doświadczeń społecznych przyspieszających rozwój umiejętności związanych między innymi ze wzrastającymi możliwościami wywierania wpływu na otoczenie (Trempała, 2001). W tym sensie 13-latek może różnić się od 12-latka pod względem ilości doświadczeń i zmian, w obliczu których staje i do których przystosowuje się w wyniku zmian instytucjonalizacji kształcenia. Tym samym zmiana etapu edukacji może być nowym doświadczeniem dla uczniów i wpływać na obniżenie ich możliwości sprawowania kontroli nad biegiem zdarzeń. Teza o zmianie 
środowiska szkolnego oraz wpływie tej nowej sytuacji na poczucie kontroli zdarzeń była już sygnalizowana w literaturze przez B. Szmigielską (1981) oraz H. Kulasa (1996, 1998).

Niniejsze badania wykazały też, że zarówno w sytuacjach sukcesów, jak i porażek poczucie kontroli u gimnazjalistów przesunięte jest w kierunku zewnętrznego. Tym samym druga hipoteza, zakładająca, że gimnazjaliści w porównaniu z uczniami szkół podstawowych charakteryzują się przesuniętym ku wewnętrznemu poczuciu kontroli w sytuacjach sukcesów, ku zewnętrznemu zaś w sytuacjach porażek, się nie potwierdziła. Otrzymane wyniki częściowo zgodne są z rezultatami uzyskanymi przez K. Barani (2006), która zaobserwowała u gimnazjalistów z klas pierwszych wyższe zewnętrzne poczucie kontroli, ale tylko w sytuacjach porażek. Uzyskane wyniki stoją natomiast w opozycji do stadialnego modelu poczucia kontroli zaproponowanego przez Elizabeth A. Lawrence i Jamesa F.Winschela (1977; za: Barani, 2006), który akcentuje wysoką internalizację porażek przy niskiej internalizacji sukcesów w okresie adolescencji, co ma wiązać się ze wzrostem samokrytycyzmu u dorastających. Otrzymane w niniejszych badaniach rezultaty wskazują, że gimnazjaliści charakteryzują się tendencją do niepodejmowania osobistej odpowiedzialności za zdarzenia, w których uczestniczą, niezależnie od tego, czy są to sytuacje związane z odnoszonymi sukcesami czy porażkami.

Badania A. Cazan i S. Dumitrescu (2016) wykazały brak istotnych różnic w poczuciu kontroli u uczniów i uczennic między 13. a 19. rokiem życia. Podobnych wniosków dostarczyły analizy prowadzone przez A. Anderson, J. Hattie i R. Hamilton (2005) w grupie 16- i 17-letnich dziewcząt oraz chłopców. B. Szmigielska (1981), na podstawie badań 304 uczniów między piątą a ósmą klasą szkoły podstawowej, także nie zaobserwowała różnic między dziewczętami oraz chłopcami. Z kolei H. Kulas (1998) w trzyletnich badań podłużnych na grupie 170 uczniów szkół podstawowych zauważył tendencję do bardziej zewnętrznego poczucia kontroli u uczennic w porównaniu z chłopcami. Należy nadmienić, że opisane przez badaczy odmienne rezultaty dotyczące poczucia kontroli u chłopców i dziewcząt mogą wynikać z różnic kulturowych oraz zastosowanych różnych narzędzi do pomiaru poczucia kontroli (Stocs, April, Lynton, 2012; Prendergast, 2001). Tym samym ze względu na liczne, ale też niejednoznaczne doniesienia $\mathrm{z}$ literatury $\mathrm{w}$ obszarze poczucia kontroli chłopców i dziewcząt w okresie adolescencji, przeprowadzono analizy z podziałem na płeć. Hipoteza trzecia, zakładająca, że dziewczęta częściej niż chłopcy charakteryzują się zewnętrznym poczuciem kontroli w zakresie zgeneralizowanego poczucia kontroli oraz w sytuacjach sukcesów i porażek, się nie potwierdziła. Otrzymane wyniki ukazały dotychczas przeprowadzone w tym obszarze badania w nowym świetle oraz potwierdziły potrzebę dalszych psychologicznych analiz poczucia kontroli z uwzględnieniem płci. Wyniki niniejszych badań ujawniły, że dziewczęta nie różnią się od chłopców w zakresie poczucia kontroli na każdym z dwóch etapów edukacji. Dodatkowo dziewczęta ze szkół podstawowych i gimnazjów także nie różnią się istotnie między sobą. Brak różnic dotyczy zarówno zgeneralizowanego poczucia kontroli, jak i poczucia kontroli w sytuacjach sukcesów i porażek. Wyniki te są zgodne z wynikami analiz B. Szmigielskiej (1981), A. Cazan i S. Dumitrescu (2016) oraz A. Anderson, J. Hattie i R. Hamilton (2005). Zauważone przez autorki artykułu różnice dotyczą tylko wyników w poczuciu kontroli pomiędzy chłopcami ze szkół podstawowych i gimnazjów. Chłopcy gimnazjaliści przejawiają istotnie statystycznie wyższe wewnętrzne poczucie kontroli w sytuacjach sukcesów oraz w zakresie zgeneralizowanego poczucia kontroli niż szóstoklasiści. Otrzymane wyniki dotyczące różnic w poczuciu kontroli chłopców można interpretować zachodzącymi we wczesnej adolescencji zmianami związanymi ze skokiem pokwitaniowym, który powoduje przeobrażenia we wszystkich sferach funkcjonowania nastolatka (Brooks-Gunn, Petersen, Eichorn, 1985; Marceau, Ram, Houts, Grimm, Susman, 2011). U chłopców skok pokwitaniowy powoduje wzrost sprawności fizycznej oraz tężyzny ciała. Zmiany w wyglądzie fizycznym w przypadku chłopców są dla nich źródłem zadowolenia, większej atrakcyjności i popularności w grupie, a tym samym nasilenia poczucia możliwości wywierania wpływu na otoczenie (Clausen, 1975; Jones, Baley, 1950). Być może 
zachodzący u chłopców z obu etapów edukacji skok pokwitaniowy powoduje, że gimnazjaliści w trakcie trwania tego procesu stają się coraz bardziej pewni siebie i przekonani o osobistej kontroli zdarzeń, szczególnie tych związanych z odnoszonymi sukcesami. Nie zauważono podobnych różnic między badanymi grupami chłopców w poczuciu kontroli niepowodzeń. W odniesieniu do dziewcząt nie zaobserwowano różnic w poczuciu kontroli między dziewczętami szóstoklasistkami i gimnazjalistkami. Badacze wskazywali, że przemiany w wyglądzie fizycznym wynikające ze skoku pokwitaniowego dla dziewcząt mogą być dużo częściej niż w przypadku chłopców źródłem poczucia zagubienia i mniejszej pewności siebie w podejmowanych działaniach (Brooks-Gunn, Reiter, 1990; Murdey, Cameron, Biddle, Marshall, Gorely, 2004). Zaobserwowane w niniejszych badaniach różnice między dziewczętami a chłopcami z uwzględnieniem dwóch etapów edukacji są głosem w dyskusji na temat roli płci w kształtowaniu się poczucia kontroli.

\section{PODSUMOWANIE}

Zaprezentowane w artykule badania stanowią rozpoznanie specyfiki poczucia kontroli we współczesnym kontekście przemian systemu edukacji w Polsce. Analizując globalnie uzyskane wyniki, można wskazać na kilka obszarów oddziaływań, które mogą wspomagać rozwój poczucia kontroli u badanych uczniów. Obecnie potrzebne jest dla wszystkich uczniów wsparcie psychologiczne umacniające ich poczucie wpływu na zdarzenia w kontekście nowej reformy, której skutków bezpośrednio doświadczają. W odniesieniu do szóstoklasistów, u których poczucie kontroli jest istotnie bardziej przesunięte $\mathrm{w}$ kierunku wewnętrznego, oddziaływania wychowawczo-edukacyjne mogą skupiać się na analizie ich mocnych i słabszych stron funkcjonowania, z zaakcentowaniem ich zasobów i kompetencji ważnych z punktu widzenia realizowanych przez nich celów edukacyjnych i osobistych. Uczniowie ci, po przejściu do siódmej klasy, pozostają w większości w tej samej placówce i z tymi samymi osobami z najbliższego otoczenia szkolnego. W związku z tym być może doświadczają mniejszego poczucia niepewności związanego z koniecznością zmiany i adaptacji do nowego środowiska szkolnego. To, czy i jak zmieni się ich poczucie kontroli, zostanie zweryfikowane w kolejnych etapach badań.

W odniesieniu do gimnazjalistów charakteryzujących się poczuciem kontroli istotnie bardziej przesuniętym w kierunku zewnętrznego należałoby rozwijać poczucie osobistej odpowiedzialności za decyzje, które podejmują. Ukazywanie związków pomiędzy intencjami uczniów, wybieranymi przez nich sposobami działania oraz konsekwencjami tychże działań może odbywać się poprzez wspólne rozwiązywanie problemów, planowanie działań i dobór właściwych sposobów realizacji ważnych celów. Warto także kształtować u uczniów postawy sprzyjające obiektywnemu dostrzeganiu własnych zasług w wyjaśnianiu przyczyn sytuacji związanych z sukcesem osobistym.

Mając na uwadze potrzebę integracji wiedzy psychologicznej z praktyką wychowawców pracujących na co dzień z młodzieżą, każdej ze szkół i klas biorących udział w badaniach udzielono informacji zwrotnej. Zostały w niej wskazane możliwości oddziaływań wychowawczych w pracy z każdą klasą w aspekcie wspierania rozwoju wewnętrznego poczucia kontroli u uczniów w tym ważnym dla nich rozwojowo momencie. Kolejne dwa etapy badań umożliwią przedstawienie zaobserwowanych zmian rozwojowych w zakresie poczucia kontroli u badanych uczniów. Szczególnie ważne będą ostateczne wyniki analiz, które wskażą na to, jak i w jakich obszarach będzie zmieniało się poczucie kontroli. Na tej podstawie będzie można określić współczesne zmiany poczucia kontroli wśród młodzieży we wczesnej adolescencji.

\section{BIBLIOGRAFIA}

Allik J., Laidra K., Realo A., Pullmann H. (2004). Personality Development from 12 to 18 years of age: Changes in mean levels and structure of traits. European Journal of Personality, 18, 445-462. 
Anderson A., Hattie J., Hamilton R.J. (2005). Locus of control, self-efficacy, and motivation in different schools: Is moderation the key to success? Educational Psychology, 25(5), 517-535.

Barani K. (2006). Poczucie umiejscowienia kontroli a styl adaptacji w pierwszej klasie gimnazjum. Psychologia Rozwojowa, 11(3), 123-133.

Bardziejewska M. (2005). Okres dorastania. Jak rozpoznać potencjał nastolatków? W: A.J. Brzezińska (red.), Psychologiczne portrety czlowieka. Praktyczna psychologia rozwojowa, 345-377. Gdańsk: GWP.

Bialer I. (1961). Conceptualization of success and failure in mental retarded children. Journal of Personality, 29(3), 203-211.

Brooks-Gunn J., Petersen A.C., Eichorn D. (1985). The Study of Maturation Timing Effects in Adolescence. Journal of Youth and Adolescence, 14(3), 149-161.

Brooks-Gunn J., Reiter E.O. (1990). The role of pubertal processes. W: S.S. Feldman, G.R. Elliott (eds.), At the Threshold: The Developing Adolescent, 16-53. Cambridge, MA, US: Harvard University Press.

Brzezińska A. (2010). Społeczna psychologia rozwoju. Warszawa: Wydawnictwo Naukowe SCHOLAR.

Brzeziński J. (2008). Psycholog wobec osób uczestniczących w badaniach psychologicznych - między poprawnością metodologiczną a poprawnością etyczną. W: J. Brzeziński, B. Chyrowicz, M. Toeplitz-Winiewska, W. Poznaniak (red.), Etyka zawodu psychologa, 115-146. Warszawa: Wydawnictwo Naukowe PWN.

Butler-Sweeney J. (2007). The relationship Among locus of control, coping style, self-esteem and cultural identification in female adolescents. Seton Hall University Dissertations and Thesis (ETDs), 1670.

Cazan A.M., Dumitrescu S.A. (2016). Exploring the relationship between adolescent resilience, self-perception and locus of control. Romanian Journal of Experimental Applied Psychology, 7(1), 283-286.

Chubb N.H., Fertman C.I., Ross J.L. (1997). Adolescent self-esteem and locus of control: A longitudinal study of gender and age differences. Adolescence, 32(125), 113-129.

Clausen J.A. (1975). The social meaning of differential physical and sexual maturation. W: S.E. Dragastin, G.H. Elder Jr. (eds.), Adolescence in the Life Cycle: Psychological Change and the Social Context. New York: Halsted, Press.

Declerck C.H., Boone Ch., De Brabander B. (2006). On feeling in control: A biological theory for individual differences in control perception. Brain and Cognition, 62, 143-176.

Dekovic M., Meeus W. (1997). Peer relations in adolescence: Effects of parenting and adolescents' self-concept. Journal of Adolescence, 20, 163-176.

Deniz M.E., Traş Z., Aydoğan D. (2009). An investigation of academic procrastination, locus of control, and Emotional intelligence. Educational Sciences Theory \& Practice, 623-632.

Domachowski W. (1984). Poczucie umiejscowienia kontroli jako wymiar osobowości. W: W. Domachowski (red.), Z zagadnień psychologii społecznej, 79-89. Warszawa: PWN.

Domańska-Najder K. (1984). Definicja pojęcia kontroli - przegląd zagadnień. Przegląd Psychologiczny, 27, 405-420.

Dominiak M. (2006). Poczucie kontroli a osiągnięcia szkolne i aspiracje edukacyjne dorastających. Ruch Pedagogiczny, 77(5-6), 81-91.

Drwal R.Ł. (1995), Poczucie kontroli jako wymiar osobowości - podstawy teoretyczne, techniki badawcze i wyniki badań. W: R.Ł. Drwal, P. Brzozowski, P. Oleś (red.), Adaptacja kwestionariuszy osobowości. Wybrane zagadnienia i techniki, 199-227. Warszawa: PWN.

Dudzikowa M., Wawrzyniak-Beszterda R. (2010). Doświadczenia szkolne pierwszego rocznika reformy edukacji. Studium teoretyczno-empiryczne. Kraków: Impuls.

Farnicka M., Liberska H. (2015). Uwarunkowania poczucia dobrostanu psychicznego u dzieci w wieku szkolnym. Problemy Wczesnej Edukacji, 4(31), 77-91.

Farnicka M., Liberska H., Nurmi J.E. (2016). Predyktory (podmiotowe i sytuacyjne) efektywnej adaptacji szkolnej - ujęcie rozwojowe. Psychologia Rozwojowa, 21(1), 21-32.

Gliszczyńska X. (1990). Konkretność i ogólność poczucia kontroli. Przeglqd Psychologiczny, 33, 597-611.

Jaworowska A. (1982), Rodzina a przystosowanie psychospołeczne dziecka. W: L. Wołoszynowa (red.), Materiaty do nauczania psychologii. Seria II, t. 9, 122-158. Warszawa: PWN.

Jones M.C., Bayley N. (1950). Physical maturing among boys as related to behavior. Journal of Educational Psychology, 41(3), 129-148. 
Kim Y. (2011). Adolescents' health behaviours and its associations with psychological variables. Central European Journal of Public Health, 19(4), 205-209.

Kliewer W., Sandler I.N. (1992), Locus of control and self-esteem as moderators of stressor-symptom relations in children and adolescents. Journal of Abnormal Psychology, 20(4), 393-413.

Krasowicz-Kupis G., Kurzyp-Wojnarska A. (1990). Kwestionariusz do Badania Poczucia Kontroli (KBPK): Podręcznik. Warszawa: Polskie Towarzystwo Psychologiczne.

Krasowicz-Kupis G., Wojnarska A. (2017). Kwestionariusz do Badania Poczucia Kontroli-wersja zrewidowana. Podręcznik. Warszawa: Pracownia Testów Psychologicznych Polskiego Towarzystwa Psychologicznego.

Kulas H. (1996). Locus of control in adolescence: A longitudinal study. Adolescence, 31(123), 721-720.

Kulas H. (1998). Rozwój poczucia kontroli u dzieci w wieku szkolnym. Psychologia Wychowawcza, 3, 219-228.

Landis B.D., Altman J.D., Cavin J.D. (2007). Underpinnings of academic success: Effective study skills use as a function of academic locus of control and self-efficacy. Psi Chi Journal of Undergraduate Research, $12(3), 126-130$.

Lefcourt H. (1976). Locus of Control: Current Trends in Theory and Research. Hillsdale, New Yersey: Erlbaum Associates.

Ng-Knight T., Schoon I. (2017). Can locus of control compensate for socioeconomic adversity in the transition from school to work? Journal of Youth and Adolescence, 46, 2114-2128.

Marceau K., Ram N., Houts R.M., Grimm K.J., Susman E.J. (2011). Individual differences in boys' and girls' timing and tempo of puberty: Modeling development with nonlinear growth models. Developmental Psychology, 47(5), 1389-1409.

Marks L. (1998). Deconstructing locus of control: Implications for practitioners. Journal of Couseling \& Development, 76, 251-260.

McCrea R.R., Martin T.A., Costa P.T. (2005). Age trends and age norms for the NEO personality inventory-3 in adolescents and adults. Assessment, 12(4), 363-373.

Moshki M., Ashtarian H. (2010). Perceived locus of control, self-Esteem, and its relations to psychological well-being status in Iranian students. Iranian Journal of Public Health, 39(4), 70-77.

Murdey I.D., Cameron N., Biddle S.J., Marshall S.J., Gorely T. (2004). Pubertal development and sedentary behaviour during adolescence. Annals of Human Biology, 31(1), 75-86.

Obuchowska I. (2009). Adolescencja. W: B. Harwas-Napierała J. Trempała (red.), Psychologia rozwoju czlowieka. Charakterystyka okresów życia człowieka. Tom 2, 163-201. Warszawa: PWN.

Obuchowski K. (1985). Adaptacja twórcza. Warszawa: Książka i Wiedza.

Piaget J. (1974). Understanding Causality. New York: Norton.

Poziemska J. (2015). Poczucie umiejscowienia kontroli zdarzeń szkolnych a osiągnięcia edukacyjne. W: Teksty z zakresu diagnostyki edukacyjnej w bazie PTDE. XXI Konferencja Diagnostyki Edukacyjnej, 474-482. Kraków: Polskie Towarzystwo Diagnostyki Edukacyjnej.

Prendergast K.S. (2001). Body image and locus of control in children and adolescents. Dissertation Abstracts International: Section B: The Sciences and Engineering, 62, 25-20.

Rotter J.B. (1966). Generalized expectancies for internal versus external control of reinforcement. Psychological Monograph, 80, 1-28.

Smith V.L. (2003). Analysis of locus of control and educational level utilizing the internal control index. Theses, Dissertations and Capstones, 881, 1-63.

Stocks A., April K.A., Lynton N. (2012). Locus of control and subjective well-being - a cross cultural study. Problems and Perspectives in Management, 10(1), 17-25.

Szmigielska B. (1981). Spostrzeganie związku pomiędzy własnym działaniem a jego następstwami przez dzieci w wieku szkolnym. Psychologia Wychowawcza, 4, 469-479.

Trempała J. (2001). Dwa przełomy w badaniach nad rozwojem psychicznym człowieka. Przeglad Psychologiczny, 44, 1, 85-92.

Turska D. (2003). Problematyka podmiotowej kontroli - analiza porównawcza najlepszych i typowych uczniów. Psychologia Rozwojowa, 8(1), 27-36.

Ustawa z dnia 14 grudnia 2016 r. Prawo oświatowe. Dziennik Ustaw 2017 poz. 59.

Woynarowska B., Małkowska-Szkutnik A., Woynarowska-Soldan M., Mazur J. (2015). Postrzeganie przez młodzież w wieku 11-15 lat wybranych aspektów środowiska psychospołecznego szkoły. Tendencje zmian w latach 1990-2010. Kwartalnik Pedagogiczny, 1(235), 185-205. 